\title{
Influence of the type of membership functions of fuzzy variables on transient processes in an electric drive
}

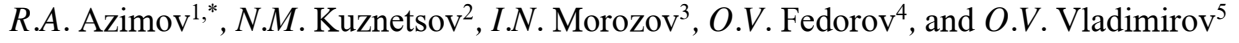 \\ ${ }^{1}$ Tajik Technical University named after academician M.S. Osimi, Dushanbe \\ ${ }^{2}$ Northern Energetics Research Centre - Branch of the Federal Research Centre "Kola Science Centre of the Russian Academy of \\ Sciences" (NERC KSC RAS), Russia, Apatity \\ ${ }^{3}$ Federal State Budgetary Educational Institution of Higher Education "Murmansk Arctic State University", Northern Energetics \\ Research Centre - Branch of the Federal Research Centre "Kola Science Centre of the Russian Academy of Sciences" (NERC KSC \\ RAS), Russia, Apatity \\ ${ }^{4}$ Nizhny Novgorod State Technical University named after R.E. Alekseeva, Russia, Nizhny Novgorod \\ ${ }^{5}$ Federal State Budgetary Educational Institution of Higher Education "Kazan State Power Engineering University", Russia, Kazan
}

\begin{abstract}
The paper deals with the influence of the type of membership functions of fuzzy variables on transient processes in an electric drive. The membership functions of fuzzy variables of S-shaped type and triangular type are proposed for consideration. To identify the dependencies of the influence of these functions, the article offers simulation modeling in the Matlab software environment, the Simulink application. The system of frequency converter - asynchronous motor (FC-AM) was chosen as the considered control system. Transient processes in the considered system with various types of membership functions are shown. The results of the work are summarized in the conclusions.
\end{abstract}

\section{Introduction}

The application of the theory of fuzzy sets is gaining more and more popularity in control systems for electric drives [1-5], the formalization of the process parameters in which is quite difficult. The approaches of the theory of fuzzy sets allow solving these problems with a certain degree of accuracy [6-8],. Often, the quality of control decisions in control systems is determined by the accuracy of tuning the knowledge base and depends on the number of expert assessments. Also, the type of membership functions at the stages of fuzzification and defuzzification has a significant impact on decision making.

The paper deals with the use of membership functions of various types. To study the operation of the electric drive, an asynchronous electric motor of the 4A series with a power of $22 \mathrm{~kW}$ was chosen. As an automatic control system, the FC-AM control system with speed feedback was chosen.

The calculation of this control system was made. The Simulink application of the Matlab program was chosen as the environment for modeling. After that, the development of a fuzzy speed controller was made.

Initially, fuzzy variables were introduced, their term sets were determined, and membership functions were set for each term set of a linguistic variable:

Two input fuzzy variables:

• "Acceleration";

- "Speed difference";

And one output fuzzy variable:
- "Current reference".

Membership functions of term-sets of fuzzy variables are shown in Figure 1. The type of these functions was S-shaped.

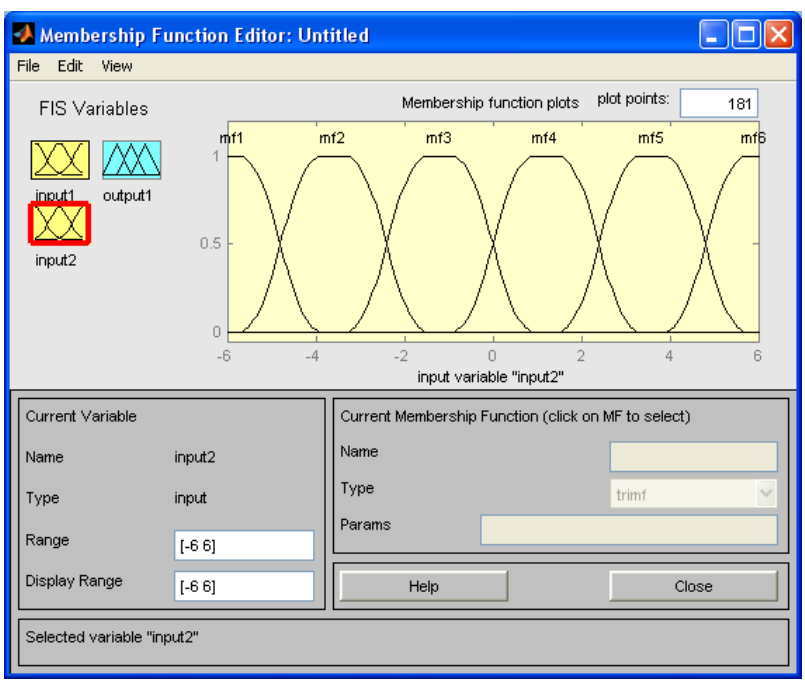

Fig. 1. Term-set of the input parameter "speed difference".

Further, the rules for fuzzy inference were defined. These rules were chosen in accordance with the expert knowledge base.

In the FIS editor, the structure of the regulator, the fuzzy inference algorithm were determined, all the parameters of the membership functions and the knowledge base were set (Fig. 2).

\footnotetext{
* Corresponding author: azimov.rahim@mail.ru
} 


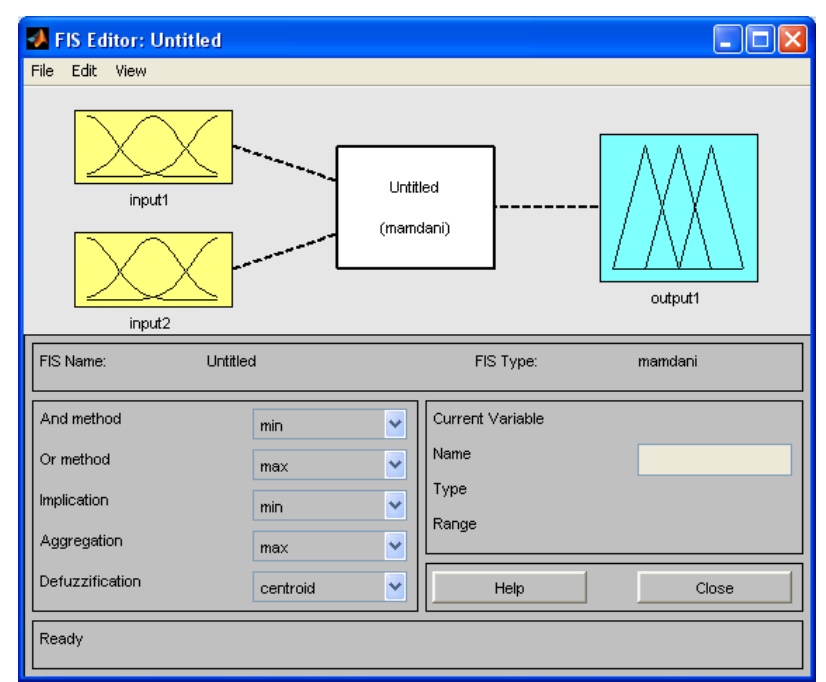

Fig. 2. Determination of the structure of the controller and the fuzzy inference algorithm.

The model using the developed fuzzy controller is shown in Figure 3.

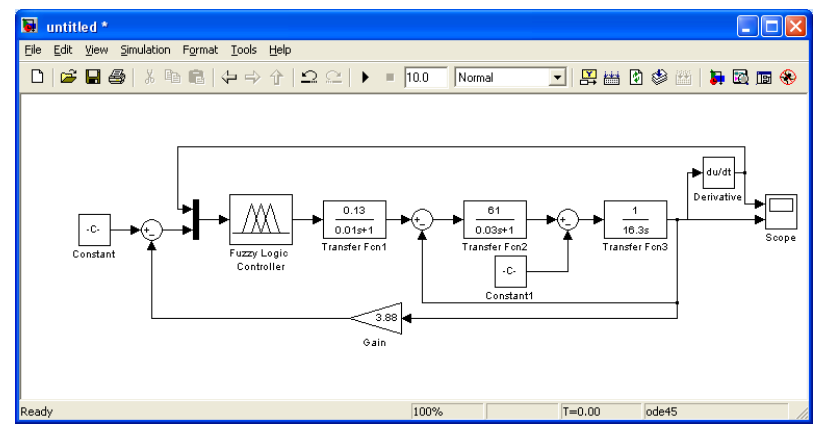

Fig. 3. Mathematical model of the drive.

Further in the work, the form of membership functions was changed to triangular.

The results of comparison of transient processes during the operation of the system with different types of regulators are shown in the oscillogram (Fig. 4).

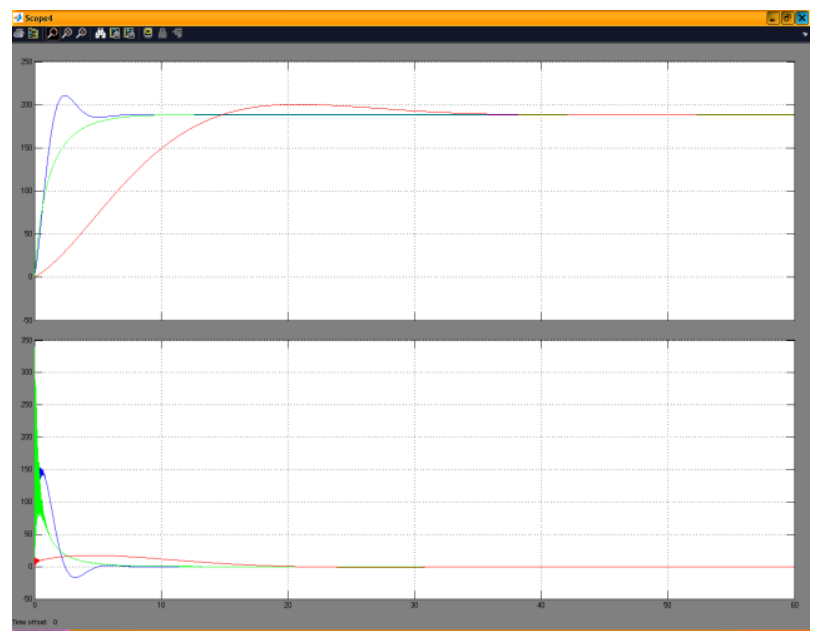

Fig. 4. Startup Transient Graphs (1 blue - PI controller; 2 green - S - shaped membership functions; 3 red - triangular membership functions).
As can be seen from the graphs obtained, the system meets the requirements of the technical specifications and operates similarly to a system with a standard PI controller. Transient studies have shown no static error. The overshoot did not exceed $10 \%$. The regulation time also did not go beyond the permissible values.

These studies were conducted in order to identify the preferred type of membership functions in the construction of automatic control systems. However, with numerous experiments, it was possible to establish the absence of an unambiguous relationship between the results of the system's operation with one or another type of membership function. The knowledge base had a significant impact on the experiments. When adjusting the base values, the simulation results sometimes changed dramatically. As a conclusion, we note that for the construction of control systems using methods of the theory of fuzzy control, an individual approach to the object is required, revealing the hidden dependencies of the parameters of which is a complex task.

\section{References}

1. Azimov R.A., Akhmedov U.M., Dzhaborov M.M. Modernizatsiya glavnogo elektroprivoda 4-kh krasochnoy poligraficheskoy mashiny. Politekhnicheskiy vestnik. Seriya: Inzhenernyye issledovaniya. 2018. № 1 (41). S. 6-13.

2. Kuznetsov N.M., Morozov I.N. Modeling of power consumption of ball mill. Gornye nauki i tekhnologii $=$ Mining Science and Technology (Russia). 2016;(4):50-61. (In Russ.) https://doi.org/10.17073/2500-0632-2016-4-50-58

3. Kuznetsov N.M., Morozov I.N. Sintez nechetkogo regulyatora proizvoditel'nosti glavnoy ventilyatsionnoy ustanovki rudnika // Podzemnaya ugledobycha XXI veka-1: Gornyy informatsionnoanaliticheskiy byulleten' (nauchno-tekhnicheskiy zhurnal) Mining Informational and analytical bulletin (scientific and technical journal): v 2-kh t. 2018. № 11 (spets. vyp. 48). M.: Izdatel'stvo «Gornaya kniga». - T. 1. - S. 336-345. DOI: 10.25018/0236-1493-2018-11-48-336-345

4. Kuznetsov N.M., Morozov I.N. Primeneniye neyrosetevogo regulirovaniya $\mathrm{V}$ upravlenii vodootlivnymi ustanovkami // Trudy NGTU im. R.Ye. Alekseyeva. - 2018. - № 4. - S. 135-142.

5. Grachova Ye.I., Ivshin I.V., Safin A.R. Razrabotka ratsional'noy skhemy upravleniya tyagovogo elektroprivoda tramvaya $\mathrm{v}$ srede modelirovaniya programmy MATLAB. Elektrika. 2015. № 6. S. 2834.

6. Shevyrov YU.V., Morgachov D.A. Issledovaniye elektromagnitnoy sovmestimosti dizel'noy elektrostantsii i glavnogo elektroprivoda burovoy ustanovki. Gornyy zhurnal. 2015. № 1. S. 62-66. DOI: $10.17580 /$ gzh.2015.01.11

7. Fashilenko V.N., Reshetnyak S.N. Energy efficient resonant mode of electromechanical systems mining machines based on management structures with the 
pid-controller, MINER'S WEEK - 2015. REPORTS OF THE XXIII INTERNATIONAL SCIENTIFIC SYMPOSIUM. 2015.p . 583-587.

8. Semenov A.S., Khubieva V.M., Kharitonov Y.S. Mathematical modeling of static and dynamic modes DC motors in software package MATLAB //2018 International Russian Automation Conference, RusAutoCon 2018. 2018. 